The Swans, by Peter Scott and the Wildfowl Trust. Michael Joseph; $£ 4.20$.

Handsomely produced, with 49 pages of plates and 242 pages of text, including bibliography and index, with a short personal introduction by Peter Scott, the meat of the book is by experts in their own fields, mostly connected with the Wildfowl Trust. The information is of the kind to be expected in a systematic work, but instead of being grouped under each species, the chapters cover separate aspects of the group as a whole, such as classification, distribution, migration, food, mortality and conservation. This is particularly apt when the the subject is 'Art and mythology'. In other cases it enables comparisons between the species to be made easily. With so small a group there is no great difficulty in finding information about a particular species.

The frontispiece is a colour reproduction of a Peter Scott painting of Bewick swans in flight. One regrets it was not a more formalised painting of the whole group in the manner usual to a book of this kind; the sacrifice of art to utility would have been worthwhile. The photographic reproductions are of uneven quality, understandably when some species seem to have been little photographed. The mute swan must be among the most photographed! In some cases the illustrative value is nil as, for example, the female swan on a nest which is barely visible although the landscape looks fine. It is nice to see again some of the classic swan photographs. There are also numerous text figures, illustrations and decorations, the last unduly numerous, and one of the distribution maps may be criticised for lack of clear differentiation between the stippling and hatching.

Dr Matthews writes the conservation chapter with clarity and simplicity, setting the particular position of the swans against the general conservation background. The most intractable difficulties relate to the breeding of Bewick's, whistling and whooper swans and the handful of trumpeters. Spreading themselves thinly over the Arctic tundra, the preservation of their habitat from disturbance and exploitation seems a slim hope. Yet these are the truly migratory swans which make the most dramatic appeal.

G. DES FORGES

\title{
Alaska the Embattled Frontier, by George Laycock. Houghton Mifflin, $\$ 6.95$
}

Written by a Field Editor of $A$ udubon and introduced by the Editor, Les Line, this first title of the Audubon Library series discusses some of the conflicts that have arisen in the Alaska environmental scene: north slope oil, Amchitka underground bomb tests and softwood clear-cutting practices in the south-eastern panhandle. The style ranges from rhetorical to polemical, an approach which has severely limited the book's potential effectiveness, value and underlying message. The author is right to draw attention to the philosophical implications of altering (irrevocably, one should add) the wilderness character of the land through exploitation of the natural resources. Furthermore, he is right in stating that the Alaskan wilderness and its wildlife belongs to the nation as a whole and that industrial interests - notably oil - and some political factions have pursued a development policy with arrogance and ecological ineptitude. But to attack this with another kind of arrogance and ineptitude will win no useful converts and will only add to the extreme polarisation that currently inhibits com- 
promise and the development of a realistic policy of ecosystem management.

The book lacks an analysis of the wildlife situation as a whole or in specific detail. One quarter concerns the sea otter; the half-million caribou rate a few lines only, and other species are assessed by the tired and inaccurate 'decimated'. Les Line's comments on wildlife in the introduction are uninformed, and the many factual and scientific errors reflect the quick-trip approach to the exceedingly complex ramifications of the Alaska wildlife picture. It is to be hoped that those conservationists thinking of coming to Alaska to walk her hills for themselves will not be put off by the author's warning that a footstep on the tundra will show for five years; one wishes that Laycock had been here at least this long before committing pen to paper.

The many very attractive photographs are of excellent quality. The dust jacket shows an Eskimo, in a parka of the eastern Canadian type, firing an arrow directly overhead. The reader may wonder whether the unseen target is an oil company helicopter or a flock of geese on spring migration.

JOHN HENSHAW

High Arctic, by George Miksch Sutton. Paul S. Eriksson, New York. $\$ 12.95$.

\section{Animals of the Arctic, by Bernard Stonehouse. Ward Lock, $£ 2.75$.}

Dr George Sutton, American ornithologist and bird-artist, made his first trip 'down north' in 1920; winter and summer, he has been there many times since, and no one else now living can look back on so long a professional involvement with wildlife in arctic Canada. His scientific contributions have been many and are highly valued by his fellow workers in the north; but it is as an artist, illustrator, lecturer and populariser that his name is most widely known to the world. High Arctic: an expedition to the unspoiled North reproduces eleven of his water-colours, eight of them in generous double-page spreads; they are marvellously evocative of the high arctic spring, depicting migrant birds newly returned, or muskoxen - the special feature of the trip the book describes - among the melting snow and the budding shrub willows. It was in 1969 that he had this opportunity of joining his younger colleague of earlier expeditions, Dr. Dave Parmelee, and others on flying visits to Bathurst and Axel Heiberg Islands, roughly 70 to 80 degrees north in the Canadian arctic archipelago. The 116 pages of text contain a simple narrative of our active weeks, and achieve their modest purpose, to carry the reader away briefly to the purity and fascination of an arctic biome, which he cannot easily get to himself. The author, a most perceptive, practical, hardy individual of 74 , who undertakes nothing without making sure it is done well, has produced an aesthetically pleasing book, well bound and printed, with many choice photographs in addition to the plates, and with small black-and-white colophons of wildfowl, jaegers and muskoxen to decorate its $10^{3 / 4} \mathrm{x}$ $8 \frac{1}{4}$-inch pages.

Dr Bernard Stonehouse's book is the same size but rather thicker (172 pages), with over 200 colour pictures in the text, most of them from photographs; many of them are strikingly beautiful or technically superlative or both. Considering this wealth of illustration the book is very moderately priced. I was sorry to find therefore, as I read it, signs of hasty preparation on the author's part, and signs that he has not had enough first-hand contact with the animals of the Arctic to justify 